\title{
Intensificação Laboral e Identidade Profissional: o Professor de Sociologia do Ensino M édio da cidade de Santa M aria/RS
}

\author{
Laura Senna Ferreira* \\ Dionas Ávila Pompeu**
}

\section{Resumo:}

Este artigo tem como objetivo explorar as atuais configurações do trabalho dos docentes da educação básica do estado do Rio Grande do Sul, com foco sobre os que ministram a disciplina de Sociologia no ensino médio das escolas público-estaduais da cidade de Santa Maria. Para tal, recorremos tanto à aplicação de questionários como à realização de entrevistas. Exercitamos o debate sobre as formas de racionalização no mundo do trabalho e suas particularidades no ambiente escolar. Focamos no conceito de intensificação e nas mudanças mais contemporâneas que ocorreram no universo laboral e seus impactos externos. Constatamos que a inadequação entre a formação inicial e a disciplina de Sociologia, bem como elementos de ordem estrutural, impacta de maneira significativa o caráter de artífice e as identidades profissionais dos docentes.

Palavras-chave: Profissão docente. Identidade Profissional. Sociologia no Ensino Médio. Racionalização do Mundo Laboral. Intensificação do trabalho.

\footnotetext{
* Professora no Programa de Pós-Graduação em Ciências Sociais (PPGCS) da UFSM. Doutorado em Sociologia pelo Programa de Pós-Graduação em Sociologia e Antropologia da Universidade Federal do Rio de Janeiro. E-mail: laurasennafe@hotmail.com

** Mestrando do Programa de Pós-Graduação em Ciências Sociais - UFSM. Membro do grupo de pesquisa Laboratório de Investigação Sociológica (LabIS) - UFSM. E-mail: dionas.apompeu@gmail.com
} 


\title{
Labor Intensification and Prof essional Identity: the Sociology T eacher of the High School of Santa M aria/RS
}

\begin{abstract}
:
This article aims to explore the current configurations of the work of teachers of basic education in the state of Rio Grande do Sul, focusing on those who teach the discipline of Sociology in high school of public-state schools of city of Santa Maria. To do this, we used both the application of questionnaires and interviews. We exercise the debate on the forms of rationalization in the world of work and their particularities in the school environment. We focus on the concept of intensification and the most contemporary changes that occurred in the labor universe and its external impacts. We found that the inadequacy between initial formation and the discipline of Sociology as well as structural elements significantly impact the craftsman character and the professional identities of teachers.
\end{abstract}

Keywords: Teaching profession. Professional Identity. Sociology in High School. Rationalization of the World of Work. Intensification of work.

\section{Intensificación Laboral e Identidad Profesional: el Profesor de Sociología de Santa M aria/RS}

\section{Resumen:}

Este artículo tiene como objetivo explorar las configuraciones actuales del trabajo de los maestros de educación básica en el estado de Rio Grande do Sul, centrándose en aquellos que enseñan la disciplina de la sociología en la escuela secundaria de las escuelas públicas estatales de Santa Maria. Para hacer esto, utilizamos cuestionarios y entrevistas. Ejercemos el debate sobre las formas de racionalización en el mundo del trabajo y sus particularidades en el entorno escolar. Nos centramos en el concepto de intensificación y los cambios más contemporáneos que ocurrieron en el universo laboral y sus impactos externos. Descu- 
brimos que la insuficiencia entre la formación inicial y la disciplina de la sociología, así como los elementos estructurales, impacta significativamente el carácter del artesano y las identidades profesionales de los maestros.

Palabras clave: Profesión docente. Identidad profesional. Sociología de secundaria. Racionalización del mundo laboral. Intensificación del trabajo.

\title{
1. Introdução
}

\begin{abstract}
Paola e Marcelo moram com seus três filhos, mas tiveram que deixar a própria casa. Em 2016, decidiram alugar o apartamento que compraram e passaram a viver com uma tia para conseguir pagar o financiamento. Por conta do aumento da carga horária nas escolas, a mãe de Paola teve que abrir mão de um dia de trabalho para cuidar das netas mais novas. Sem reajuste e com os salários parcelados há mais de 30 meses, os dois se dizem sem perspectivas e chamam atenção para as perdas da educação pública nesse processo $(17 / 07 / 2018)^{1}$.
\end{abstract}

É dessa forma que o sítio "Sul 21" resumiu a situação de vida do casal gaúcho de professores Paola e Marcelo. Como podemos observar, a profissão docente, assim como os demais conjuntos de profissões, suscita uma gama de problemáticas que podem ser submetidas à análise. Tendo esse fato em mente, a intenção deste artigo é explorar e apresentar algumas das questões vivenciadas por essa categoria na realidade de sua atividade laboral, levando em consideração não somente os dramas, mas também as potencialidades criativas para lidar com as possíveis adversidades.

Para tanto, recorremos a dados tanto de fonte primária como secundária. Estes dizem respeito à entrevista gravada em vídeo,

1 Sul 21. Como fica a vida dos professores após mais de 30 meses de parcelamento? Disponível em: $<$ https://bit.ly/2NKxSRc $>$. Acesso em: 20/04/2018. 
reportagens jornalísticas e pesquisas de órgãos governamentais como as do Institutos Nacional de Estudos e Pesquisas Educacionais Anísio Teixeira (Inep). No que toca aos dados levantados por nós, contamos com questionários aplicados nas datas $11 \mathrm{e}$ 12 de maio de 2017, bem como entrevistas (acompanhadas de questionários) empregadas no período entre o segundo semestre de 2017 e o primeiro semestre de 2018.

Trata-se de uma pesquisa com recursos quali-quanti (Martins, 2007), mas de premissa fundamentalmente qualitativa, que toma por base tanto informações de ordem objetiva como o universo de significados presente nas narrativas dos sujeitos entrevistados. Como bem sublinhou Maria Minayo (1994, p. 22), "a pesquisa qualitativa trabalha com o universo de significados, motivos, aspirações, crenças, valores e atitudes”.

Os questionários realizados nos dias 11 e 12 exploram questões tais como formação, disciplinas ministradas, carga horária, interesse temático em curso de formação, entre outras, e abarcam professores que atuam tanto no ensino fundamental quanto no médio (isto é, na educação básica de forma geral) ${ }^{2}$. No caso das entrevistas $^{3}$, estas foram realizadas com professores que ministram a disciplina de Sociologia nas escolas público-estaduais da cidade de Santa Maria/RS ${ }^{4}$. Justificamos tal escolha por duas vias.

A primeira é por viés metodológico, ou seja, entendemos que afinar a análise dos dados nos permite explorar maiores questões de determinado objeto. A segunda diz respeito a problemáticas de ordem educacional do país, isto é, professores e professoras mi-

2 Maiores esclarecimentos acerca dessa coleta de dados se encontram na subseção 3.1. Apresentação dos dados objetivos.

3 Maiores esclarecimentos sobre os critérios para as entrevistas estão na seção 3. Intensificação laboral e suas implicações no trabalho docente.

4 Destacamos que as questões presentes nos questionários dos dias 11 e 12 também se encontram naqueles aplicados juntamente às entrevistas. É por isso que consideramos válido e coerente a sua utilização em conjunto. 
nistrando disciplinas que não condizem com a trajetória formativa percorrida. Levando em consideração o censo escolar de 2017 realizado pelo Inep, no qual apenas $29,5 \%$ dos e das docentes de Sociologia do país têm formação na área das Ciências Sociais, optamos por destacar a disciplina e os respectivos profissionais por compreender que tal fato tem implicações relevantes sobre estes sujeitos, bem como para a educação de modo geral. Ainda, sublinhamos que a disciplina de Sociologia possui um histórico de intermitência nos currículos do Ensino Médio das escolas brasileiras (Moraes, 2011), fato que pode ser verificado atual e novamente na Reforma do Ensino Médio proposta pelo governo do presidente Michel Temer (PMDB) em 2016 e continuada no governo de Jair Bolsonaro (PSL) em 2019. Destaca-se que tal Reforma retira a obrigatoriedade da disciplina de Sociologia e passa a dilui-la em "estudos e práticas" ${ }^{2}$. Consideramos que esses aspectos também impactam de forma significativa a prática e a vida dos docentes.

Tendo por base essa breve reflexão introdutória, destacamos que o objetivo central aqui é compreender os desafios teóricos e empíricos estabelecidos pela extensão desta pesquisa, a saber, os percursos formativos e identidades laborais das professoras e professores da educação básica do estado do Rio Grande do Sul, com recorte específico sobre aqueles e aquelas que ministram a disciplina de Sociologia no ensino médio das escolas público-estaduais da cidade de Santa Maria. Igualmente, buscamos analisar aspectos dos processos de reestruturação recentes do trabalho docente que implicam em intensificação laboral, visto que entendemos como um fator de relevante impacto para a constituição da identidade profissional.

Dalila Oliveira (2004) afirmou que a partir da reestruturação produtiva dos anos 1990 no Brasil, o professor passou a se de-

5 Cf. em sítio do Ministério da Educação, mais precisamente no item 9 da seção de dúvidas acerca da Reforma do Ensino Médio. Disponível em: <https://bit.ly/2KF5L1g>. Acesso em: 24/04/2018. Grifos nossos. 
frontar com novas exigências advindas do campo escolar como um todo. As implicações, segundo ela, foram de intensificação e precarização do trabalho docente, entendido como o acréscimo de funções que o professor passa a adotar, o que resultou em maiores degradações e descontentamentos face sua profissão. Um desses elementos que iremos explorar é a questão da Gestão Democrática nas escolas. Além do mais, Jinkings (2009, p. 05) ainda pontuou que os estudos e pesquisas na área do trabalho docente "têm apontado para um processo de pauperização dos professores, submetidos à baixa remuneração, a longas jornadas laborais, ao multiemprego e ao subemprego, a precárias condições formativas e de trabalho". Fundamental frisar que essas alegações podem servir como um pontapé inicial, mas nunca tomadas como verdades absolutas e generalizantes. A verdade é que se precisou passar pelo exercício da verificação empírica e metódica para se ter noção em qual grau de precisão essas afirmações fazem diálogo com a realidade do trabalho docente na cidade que se está a verificar.

\section{Precariedade e crise no mundo do trabalho}

Iniciaremos esta seção abrindo um leque mais geral no qual traçamos parte da localização social do objeto aqui tratado. Temos no nosso entendimento que o profissional-professor se encontra no interior daquilo que Ricardo Antunes (1999, p. 101) chamou de "classe-que-vive-do-trabalho", um termo guarda-chuva que "compreende a totalidade dos assalariados, homens e mulheres que vivem da venda de sua força de trabalho, não se restringindo aos trabalhadores manuais diretos", mas "incorporando também a totalidade do trabalho social, a totalidade do trabalho coletivo" (Alves; Antunes, 2004, p. 342).

Levar em consideração esse aspecto é já compreender que o docente compartilha dilemas comuns ao coletivo dos trabalhadores. Citamos como exemplo o que consideramos mais estrutural, 
a saber, o fenômeno do "movimento contemporâneo de reorganização produtiva que afeta os modos de gestão e a divisão social e técnica do trabalho" (Jinkings, 2009, p. 02). Para nós essa questão é fundamental para o debate que será desenvolvido posteriormente.

Por outro lado, destacamos também que a profissão docente possui suas especificidades e que esses impactos mais estruturais chegam de maneira particular neste campo. Um breve parêntese apenas para pontuar a noção de profissão utilizada aqui. Sem adentrar em um resgate histórico e terminológico da questão, sublinhamos que nos afastamos da perspectiva anglo-saxônica da sociologia das profissões para nos filiarmos ao ponto de vista de Claude Dubar $(2005 ;$ 2012). Diferentemente da primeira concepção, que considera profissão somente aquelas que implicam existência de um diploma universitário, são "beneficiadas por uma legislação que protege seu exercício e permite às suas associações deter o monopólio de sua formação e certificação" (Dubar, 2012, p. 356), Dubar (idem, p. 364) expande tal noção:

Todos os "trabalhos", mas também todos os "trabalhadores", independentemente de gênero, cor ou religião, têm direito à qualificação de profissional, [...] do ponto mais alto ao mais baixo da escala social, do médico à auxiliar de enfermagem, do engenheiro ao operário, do professor universitário à professora auxiliar do ensino básico. [...] Com a condição de que esses "trabalhos" sejam organizados, definidos, reconhecidos como "ofícios", isto é, atividades que requerem competências que possam ser certificadas ${ }^{6}$.

Fechado o parêntese, focamos novamente na dimensão estrutural do debate. No livro "Mais trabalho! A intensificação do labor na sociedade contemporânea", Sadi Dal Rosso (2008) buscou verificar em que graus se encontram os níveis de intensidade em

6 "O problema”, chamou atenção o autor, "é o trabalho informal não declarado, não reconhecido e não acompanhado de uma oportunidade de formação certificadora" (DUBAR, idem). 
diversos ramos de atividades ${ }^{7}$ no Distrito Federal atualmente. Antes de mais nada, realiza uma exposição conceitual do que seria para ele a intensificação - apresentação esta que lançaremos mão mais adiante. 0 que gostaríamos de destacar neste momento é sua visão acerca das dimensões mais estruturais da organização do trabalho.

A afirmação do autor é "de que a história do trabalho conheceu e conhece várias e distintas práxis de intensificação, cuja manifestação contemporânea constitui apenas mais uma onda" (idem, p. 46). A sua explanação, neste sentido, indo em direção à divisão proposta pelo sociólogo Luc Boltanski e pela socióloga Ève Chiapello $(2009)^{8}$, visou "identificar pelo menos três grandes vagas de intensificação" (idem, p. 43), a saber, a Revolução Industrial; o taylorismo e o fordismo; e o toyotismo. Estas formas de organização do trabalho (que segundo o autor objetiva, entre outras coisas, o aumento da intensificação do trabalho, ou seja, maior exploração (idem, p. 45), sociologicamente, não se tratam de eventos isolados, e "sim de uma condição geral [...], fixada em regras e normas de conduta, em habitualidade, constituindo um padrão de organização que, portanto, independe dos desejos, das vontades e das características específicas de cada trabalhador" (idem, p. 43). É por esse caminho que entendemos que o professor, mesmo com suas particularidades, ainda compartilha de situações mais gerais do mundo do trabalho que atinge outras categorias e atividades.

Consideramos que o toyotismo - enquanto “'ideologia orgânica' do novo complexo de reestruturação produtiva” (Alves, 2011, p. 43) - bem como o neoliberalismo, compreendido aqui como "sistema normativo [...] capaz de orientar internamente a prá-

7 Bancos e finanças, telefonia e comunicação, supermercados, ensino privado, construção civil, serviço público.

8 Dal Rosso pelo viés da intensificação, Boltanski e Chiapello (2009, p. 39, grifo nosso) pela lógica do espírito, isto é, "a ideologia que justifica o engajamento no capitalismo". 
tica efetiva dos governos, das empresas e, para além deles, de milhões de pessoas que não tem necessariamente consciência disso" (Dardot; Laval, 2016, p. 15), são merecedores de apontamentos para melhor compreensão no que diz respeito ao nosso estudo. Do primeiro, que iremos destacar novamente mais adiante, sublinhamos que se trata não somente de inovações nos aparatos tecnológicos, mas também de transformações no âmbito do gerenciamento do trabalho e em sua lógica discursiva (Boltanski; Chiapello, idem). Como bem sublinhou Giovanni Alves (idem, p. 94), esse espírito do toyotismo, sintetizado num gerenciamento sob "critérios de produtividade e desempenho", transborda da esfera da empresa privada e se dissemina pela sociedade como um todo.

Para melhor compreender o ponto de vista da gestão organizacional, "que se apresenta como sistematização e inscrição de práticas forjadas no âmbito das empresas em regras de conduta de caráter geral", Boltanski e Chiapello (idem, p. 85, grifos nossos) analisaram a literatura empresarial "destinada a executivos"9 (idem). Nesse trabalho os autores verificaram que, respaldados em obras fundamentadas "em visões normativas que levem em conta não só as aspirações pessoais a garantias e à autonomia, mas também o modo como essas aspirações podem ser vinculadas a uma orientação mais geral para o bem comum" (idem, p. 85, grifos nossos), os livros enfocam numa maior "rejeição à hierarquia" e a "todas as instâncias associadas à autoridade (patrões, chefes, ordens, etc.)" (idem, p. 98-99, grifos do original), prometendo "igualdade formal e respeito às liberdades individuais" (idem, p. 99), visando "aumentar a autonomia das pessoas e das equipes" (idem, p. 111). Além disto, se sobressai uma "atenção obsessiva à adaptação, à mudança, à 'flexibilidade'” (idem,

9 Apesar de sublinharmos a discussão no plano dos anos 1990, os autores fazem um trabalho de comparar os discursos produzidos neste ano com os que foram elaborados nos anos 1960. 
p. 100, grifos nossos). Estas últimas observações vão ao encontro da "lógica concorrencial", elemento fundamental na argumentação desses autores, "principalmente porque a desaceleração do crescimento dos últimos vinte e cinco anos e o aumento do número de desempregados reforçam a convicção de que o desenvolvimento econômico se tornou mais difícil, e a luta econômica, impiedosa" (idem, p. 101).

Ainda no que diz respeito à gestão empresarial, gostaríamos de mencionar o transbordamento desta questão. Acompanhando essas transformações de ordem organizacional e tecnológica, podemos verificar, juntamente com Dardot e Laval, a figura do neoliberalismo. Como bem já mencionado, o neoliberalismo é entendido por esses autores como um sistema normativo, ou melhor, "é em primeiro lugar e fundamentalmente uma racionalidade e, como tal, tende a estruturar e organizar não apenas a ação dos governantes, mas até [...] a dos governados" (Dardot; Laval, 2016, p. 17, grifo do original). Neste sentido, o neoliberalismo "produz certos tipos de relações sociais, certas maneiras de viver, certas subjetividades", ou seja, "com o neoliberalismo o que está em jogo é nada mais nada menos que a forma de nossa existência, [...] a forma como somos levados a nos comportar, a nos relacionar com os outros e com nós mesmos" (idem, p.16, grifos nossos).

Precisando ainda mais a definição, Dardot e Laval consideram o neoliberalismo "como um conjunto de discursos, práticas e dispositivos que determinam um novo modo de governo dos homens segundo o princípio universal da concorrência" (idem, p. 17, grifo nosso). Sendo assim, como seria a tipologia da ação individual frente à competição no mundo? Em síntese: as pessoas gerenciariam suas vidas como se estivessem gerenciando uma empresa. Isto quer dizer que o "indivíduo deve governar-se a partir de dentro por uma racionalização técnica de sua relação consigo mesmo. Ser 'empreendedor de si mesmo'”, continuaram os autores, "significa conseguir ser o instrumento ótimo de seu 
próprio sucesso social e profissional" (idem, p. 350). E mais: “a instauração de técnicas de auditoria, vigilância e avaliação visa a aumentar essa exigência de controle de si mesmo e bom desempenho individual" (idem). Destacamos que são nesses termos que compreendemos o transbordamento da gestão empresarial para outros âmbitos da vida social.

Dito isto, gostaríamos de sublinhar que por esses vieses iremos nos ocupar da gestão democrática na escola - entendida como um método organizacional inspirado justamente na lógica contemporânea de negação das hierarquias e maior participação dos empregados nas decisões - bem como observando estratégias/projetos individuais que os profissionais entrevistados se ocupam para lidar com o seu cotidiano. Antes, porém, fazemos questão de pontuar uma problemática fundamental que já fora mencionada.

A reorganização do trabalho, apesar de ocorrer de uma maneira geral no mundo laboral, não é uniforme. Valendo-se do conceito de intensidade - o qual iremos desenvolver adiante e que está umbilicalmente ligado às formas de gerir o trabalho -, Dal Rosso (idem, p. 150) destaca que o processo de intensificação em curso "não é homogêneo em todos os campos em que se manifesta, existindo uma diversidade de formas de fazê-lo empregada por tipos de atividade". Neste sentido que deixamos claro que não se trata aqui de aplicar de forma mecânica as teorias das escolas de gestão - como o toyotismo, por exemplo - para observar o trabalho docente. 0 que pretendemos, enquanto parte deste estudo, é analisar a maneira como se organiza o trabalho do professor frente à reestruturação contemporânea no mundo do trabalho, observando o que se aproxima e o que se distancia das manifestações aqui idealmente expostas. Isto porque consideramos que tais modificações estão presentes na conformação dos desenhos identitários desses profissionais. Sendo assim, a pergunta seguinte é: sendo que a escola pública faz parte, teoricamente, das "instituições [...] centradas nos serviços aos particulares e não 
orientados pelo lucro" (Dubar, 2005, p. 193), de que forma essas transformações mais recentes no mundo do trabalho chegam a este ambiente?

Christian Laval (2004, p. 16-17, tradução nossa, grifo do original) sustenta "que uma das principais transformações que tem afetado o âmbito educativo nas últimas décadas [...] é a monopolização progressiva do discurso e da dinâmica reformadora pela ideologia neoliberal". Segundo o autor, "as reformas que, em escala global, impulsionam a descentralização, padronização de métodos e conteúdos, a nova 'gestão empresarial' das escolas e a 'profissionalização' dos professores são fundamentalmente centradas na competitividade" (idem, p. 19-20, tradução nossa). Contudo, Laval (idem, p. 21) destaca que aquilo que chamou de "escola neoliberal"10, produto do que acabamos de expor, "segue sendo uma tendência e não uma realidade consumada", uma hipótese a ser verificada na singularidade do campo escolar. Feito este devido apontamento, traremos alguns elementos do contexto brasileiro.

De acordo com Dalila Oliveira (2004) a década de 1990 é um marco para a educação brasileira, sobretudo no primeiro governo de Fernando Henrique Cardoso (1995-1998). É nesse contexto que surgem políticas educacionais de destaque, trazendo conteúdos como:

A centralidade atribuída à administração escolar nos programas de reforma, elegendo a escola como núcleo do planejamento e da gestão; o financiamento per capita, com a criação do Fundo de Manutenção e Desenvolvimento do Ensino Fundamental e de Valorização do Magistério (FUNDEF), por meio da Lei n. 9.424/96; a regularidade e a ampliação dos exames nacionais de avaliação (SAEB, ENEM,

10 "A escola neoliberal designa um certo modelo escolar que considera a educação como um bem essencialmente privado e cujo valor é acima de tudo econômico" (Laval, idem, p. 18, tradução nossa). 
ENC), bem como a avaliação institucional e os mecanismos de gestão escolar que insistem na participação da comunidade (OLIVEIRA, idem, p. 1130, grifos do original).

Conforme a autora, esses fatos "trazem medidas que alteram a configuração das redes nos seus aspectos físicos e organizacionais", tendo como pano de fundo a incorporação "das teorias administrativas as orientações para o campo pedagógico", ou seja, produtividade, eficácia, excelência e eficiência" (idem, grifos nossos). Enfim, realizada a tentativa de tecer apontamentos sobre a chegada das transformações mais gerais no mundo do trabalho na escola, relembramos que daremos atenção aqui para o âmbito da gestão da escola de modo geral, da gestão democrática e da gestão de si mesmo. Antes de avançarmos, porém, fazemos questão de mencionar brevemente o tema da gestão democrática. Como bem destacou Dalila Oliveira (2009, p. 34), era um jeito de estabelecer de forma compartilhada e acordada o horizonte pedagógico da escola, "explicitando seu currículo, seus projetos e programas e sua maneira de organizar seus processos de trabalho". Dito em outras palavras:

no Brasil, a partir da consagração na Constituição Federal de 1988, do princípio da gestão democrática do ensino público, Artigo 206, Inciso VI e da promulgação da Lei de Diretrizes e Bases Nacionais, Lei n. 9394/96, sobretudo nos artigos 12, 13 e 14, os trabalhadores docentes passaram a ter a obrigação legal de participar da gestão da escola, da escolha direta para diretores e coordenadores escolares, da representação junto aos conselhos escolares (Oliveira, idem, p. 36).

Cumprida essa menção mais geral, deslocamos a profissão docente para percebê-la a partir de um ponto de vista mais específico do que referido no parágrafo anterior. Realçamos aqui as particularidades e implicações específicas que a prática docente possui. Para tal, sublinhamos o caráter artesanal desse trabalho, em razão da sua desvinculação da dinâmica da alta 
e maquinal produção fabril. "Habilidade artesanal”, afirmou o sociólogo Richard Sennett (2009, p. 19), "designa um impulso humano básico e permanente, o desejo de um trabalho benfeito por si mesmo". Ouvimos com frequência dos entrevistados o desejo de que seu trabalho seja realizado com qualidade. "O bom artífice”, continuou Sennett (idem, p. 22), "utiliza soluções para desbravar novos territórios; a solução de problemas e a detecção de problemas estão intimamente relacionadas em seu espírito". Da mesma forma que "se imprime na narrativa a marca do narrador, como a mão do oleiro na argila do vaso" (Benjamin, 1987, p. 205), se reveste na aula o rastro da particularidade do professor, tendo este a escola e a sala de aula como laboratórios para o exercício de sua capacidade inventiva, criativa e autônoma.

\section{Intensificação Laboral e suas Implicações no T rabalho Docente}

Feita a devida apresentação desta seção, gostaríamos de explorar a discussão acerca da intensidade do trabalho docente e suas consequências. Como bem destacou Dal Rosso (2008, p. 20), "a compreensão da noção de intensidade supõe ainda que a atenção esteja concentrada sobre a pessoa do trabalhador", excluindo "outros componentes do processo de trabalho que têm capacidade de alterar os resultados, tais como as condições tecnológicas", ou seja, "a intensidade tem a ver tão-somente com o sujeito do trabalho, com o trabalhador individualizado ou com o coletivo dos trabalhadores". Não à toa Dal Rosso lançou mão de "entrevistas, registradas em questionários com perguntas fechadas e abertas para captar a realidade da intensidade vigente na atualidade" (idem, p. 94)

Antes de mais nada, gostaríamos de fazer uma breve excursão sobre as formas de gestão laboral mais conhecidas historicamente. Sem entrarmos de forma aprofundada na primeira vaga 
ou espírito ${ }^{11}$, trata-se de discutir elementos pontuais - porém fundamentais - do taylorismo, bem como do toyotismo - não deixando de mencionar a "ponte" entre os dois. Destacamos que no nosso entendimento dedicar linhas a esse debate é fundamental, visto que as formas de gerir o trabalho humano estão umbilicalmente ligadas ao conceito de intensificação.

Comecemos essa discussão tocando no sentido de uma palavra. Harry Braverman (1987, p. 68, grifos do original) muito bem nos lembrou que etimologicamente "o verbo to manage (administrar, gerenciar), vem de manus, do latim, que significa mão". Se em épocas passadas o termo "significava adestrar um cavalo nas suas andaduras", para o capitalista se trata de um empenho, "através da gerência (management), em controlar" (idem, grifos do original). "E o controle é”, continuou Braverman, "o conceito fundamental de todos os sistemas gerenciais, como foi reconhecido implícita ou explicitamente por todos os teóricos da gerência" (idem).

Braverman ressaltou, contudo, que "o controle de turmas grandes de trabalhadores antecede de muito à época burguesa" (idem, p. 65). A diferença é que se antigamente se lidava com um trabalho feito por escravos, como na construção das pirâmides, por exemplo, no capitalismo se utiliza mão de obra assalariada, a qual representa um custo no interior do estímulo do capitalista em "exibir um excedente e acumular capital" (idem, p. 66). A consequência é que esse fato "ensejou uma arte inteiramente nova de administrar, que mesmo em suas primitivas manifestações era muito mais completa, autoconsciente, esmerada e calculista do que qualquer coisa anterior" (idem).

Sublinhamos que quando o autor se refere ao controle, ele está se referindo, de maneira geral, às "formas" de se organizar o 
trabalho. Conforme Braverman, “os economistas clássicos, [...] seguidos por homens como Andrew Ure e Charles Babbage, [...] foram os primeiros a cuidar, de um ponto de vista teórico, dos problemas da organização do trabalho no seio das relações capitalistas de produção" (idem, p. 82). Contudo, ressalta o autor, nenhum desses levou tão a fundo a tarefa de organizar o trabalho de forma tão metódica quanto Frederick Winslow Taylor (1856-1915).

Taylor, que fora engenheiro mecânico norte-americano, iniciou o movimento da gerência científica no final do século XIX. Conforme Braverman (idem), "a gerência científica [...] significa um empenho no sentido de aplicar os métodos da ciência aos problemas complexos e crescentes do controle do trabalho nas empresas capitalistas em rápida expansão". Maurício Tragtenberg (2006, p. 88, grifos do original) destacou, por sua vez, que na essência do "método Taylor [...], presidindo tudo, está uma atitude descritiva na qual o importante é o como e não o porquê da ação".

Baseado em uma alta divisão do trabalho, onde de um lado estão os que executam e de outro estão os que planejam, o "como" que se deve realizar as atividades é repassado pela direção após estudos empíricos, "predominando, [assim], a organização sobre o homem"12 (idem, p. 92). Para essas pesquisas, como pon-

12 "Taylor elevou o conceito de controle a um plano inteiramente novo quando asseverou como uma necessidade absoluta para a gerência adequada a imposição ao trabalhador da maneira rigorosa pela qual o trabalho deve ser executado. Admitia-se em geral antes de Taylor que a gerência tinha o direito de 'controlar' o trabalho, mas na prática esse direito usualmente significava apenas a fixação de tarefas, com pouca interferência direta no modo de executá-las pelo trabalhador. A contribuição de Taylor foi no sentido de inverter essa prática e substituí-la pelo seu oposto. A gerência, insistia ele, só podia ser um empreendimento limitado e frustrado se deixasse ao trabalhador qualquer decisão sobre o trabalho. Seu 'sistema' era tão-somente um meio para que a gerência efetuasse o controle do modo concreto de execução de toda atividade no trabalho, desde a mais simples à mais complicada. Nesse sentido, ele foi o pioneiro de uma revolução muito maior na divisão do trabalho que qualquer outra havida" (Braverman, 1987, p. 86, primeiros grifos do original, segundos nossos). 
tuou Braverman (idem, p. 99), Taylor selecionava 1 a cada 8 "dos melhores trabalhadores, isto é, atípicos” (Tragtenberg, idem, p. 93), para gerar dados nos quais era possível observar a execução de tarefas em ritmos mais rápidos que o normal (idem). Neste sentido que "o chamado 'estudo do tempo"' (Pinto, 2010, p. 30) - ou seja, o da cronometragem - e dos movimentos "definem-se como pedra angular [do] sistema de racionalização do trabalho" em Taylor (idem, p. 90, grifo do original). Em síntese: o que Taylor fez foi, "dentro das condições técnicas vigentes" (Dal Rosso, idem, p. 58), atuar "sobre a organização do trabalho e aí introduzir transformações” (idem, p. 62, grifos nossos) ${ }^{13}$.

Antes de pontuarmos algumas características do toyotismo, prezamos em mencionar um dos elementos intermediários entre o taylorismo e o toyotismo, destacamos que Elton Mayo (18801949) e sua Escola das Relações Humanas (Tragtenberg, idem), antes mesmo de Taiichi Ohno (1912-1990) ${ }^{14}$, introduziu em seu modelo de gestão do trabalho princípios que podemos considerar de ordem mais horizontais. Trata-se fundamentalmente da busca do consenso ao invés do conflito entre os trabalhadores, ou seja, acentuou "o papel da negociação e compromisso" (Tragtenberg, idem, p. 104), buscando a harmonia por meio da psico-

13 É por dedicarmos maior atenção às formas de organização do trabalho - e não às técnicas - que resolvemos não explorar o fordismo. Conforme Dal Rosso (idem, p. 5657), “a proposta da 'administração científica do trabalho' constitui o exemplo claro de um processo de elevação do grau de intensidade, sem que sejam necessárias alterações profundas na estrutura tecnológica existente. Mudanças técnicas de peso acontecem com a modernização do sistema taylorista pela capacidade de Henry* Ford de adaptar os sistemas de cadeias produtivas ou esteiras rolantes empregados nos abatedouros de animais para a produção em massa de automóveis e outros produtos industriais. As características centrais do 'método da administração científica' proposto por Taylor como a forma de aumentar o rendimento do trabalho são mantidas e aprofundadas por meio dos controles mecânicos do ritmo e da velocidade do trabalho".

*No livro aparece o nome como John Ford. Tomamos a liberdade de modificá-lo na nossa citação por acreditar que houve um equívoco no original, visto que John Ford foi um cineasta norte-americano.

14 Ohno foi o engenheiro da fábrica Toyota que reestruturou a forma de organização da empresa, dando origem ao modelo de gestão conhecido como toyotismo. 
logia. Ainda procurou a "valorização do informal, [...] da comunicação afetiva e simbólica, levando à noção das dinâmicas de grupo, [...] uma pedagogia em nível grupal e uma ação que visa mais a formação do que a seleção" (idem, grifos do original). A crítica de Tragtenberg é que apesar da Escola ter por intenção ressaltar "a participação no processo decisório, [...] esta decisão já é tomada de cima, a qual ele apenas reforça” (idem).

É no toyotismo - como ficou conhecido o modelo proposto por Ohno -, contudo, que essa lógica mais flexível e horizontal se institucionalizou - como tivemos a oportunidade de observar na discussão realizada anteriormente, sobretudo com Boltanski e Chiapello, bem como com Laval e Dardot. A pretensão aqui será a de pontuar suas características básicas e fundamentais ${ }^{15}$, as quais se sintetizam em dois pilares de sustentação que buscam extinguir o desperdício. Trata-se do just-in-time/kanban e da autonomação. 0 primeiro é relativo, respectivamente, ao método e à ferramenta que faz com que este método funcione. A proposta era a de flexibilizar a produção pela utilização de meios de trabalho aptos a ajustar a capacidade produtiva a uma demanda variável em volume e composição. 0 sistema kanban poderia ser considerado o mensageiro que avisa qual o momento certo para produzir peças e encaminhá-las de um setor para outro sem deixar gerar estoques. Já a autonomação dá existência à fluidez na produção. Isto porque esse princípio fazia com que a máquina funcionasse sozinha, dando maior margem de liberdade para o funcionário. Como bem destacou Giovanni Alves, "essa nova organização da produção e do trabalho significa o abandono da organização do trabalho em postos fixos e especializados" (2011, p. 49).

15 Para maior compreensão acerca das origens sócio-históricas, bem como de outras questões relacionadas a esse modelo, cf. Giovanni Alves. Trabalho e Subjetividade: o espírito do toyotismo na era do capitalismo manipulatório (2011) e Ricardo Antunes. Os sentidos do trabalho: ensaio sobre a afirmação e a negação do trabalho (1999). 
Gostaríamos ainda de abordar aquilo que Alves chamou de "nexo essencial do toyotismo". Segundo o autor, trata-se da captura da subjetividade. Se em Taylor havia a clara separação entre concepção e execução, no projeto de Ohno se leva em consideração também a cabeça do operário. Assim, o "operador de base" acabou ganhando "certa 'polivalência' (pois é preciso saber intervir em diversos tipos de materiais) e certa 'poliatividade' (mesclando tarefas de fabricação, de discussão, de manutenção trivial, até mesmo, de gestão produtiva)" (idem). Em síntese: não se requer apenas que o trabalhador se subordine no aspecto formal-material, mas também no espiritual. Trata-se não somente de "máquinas inteligentes, mas sim operadores 'inteligentes, trabalhando em equipe, com habilidade e talento para dar palpites que aprimorem a inteligência do autônomo espiritual" (idem, p. 57).

Relembramos que o debate trazido aqui sobre essas formas de gestão laboral tem a ver com o fato de que elas foram desenvolvidas justamente com o propósito da intensificação do trabalho. Mas de que forma também poderíamos medir esse conceito? Levando em consideração que as técnicas para o levantamento de dados empíricos acerca da intensidade do trabalho são, conforme destacado por Dal Rosso (idem, p. 91), “a observação de situações criadas em laboratório ou de situações existenciais em processos concretos de trabalho" e os "diálogos mantidos pelos pesquisadores diretamente com os trabalhadores, ou indiretamente com seus representantes sindicais ou empregadores", optamos por analisar de forma mais aprofundada os cinco professores que, para além dos questionários, também foram entrevistados.

Fazemos questão de esclarecer alguns pontos acerca das entrevistas. A ideia base para iniciar esta pesquisar era a de selecionar quatro professores que ministravam a disciplina de Sociologia em escolas públicas e estaduais da cidade de Santa Maria, sendo dois atuantes da região central e dois de regiões mais periféricas. 0 critério para a seleção dos entrevistados 
partiu inicialmente de uma escolha racional dos pesquisadores para depois adentrar na lógica das indicações, ou seja, o professor entrevistado indicava para entrevista futura um colega que se enquadrava no recorte do objeto. Esse critério de seleção foi utilizado visando gerar uma rede de interlocutores que evitasse a todo o custo o caráter enviesado dos dados.

Ademais, como será possível observar logo adiante, resolvemos ainda utilizar uma entrevista que fora feita com um professor que na época atuava em um município próximo de Santa Maria. Tal escolha veio após a informação de que tal docente iria ser transferido para a cidade que comporta o objeto desta pesquisa. A ideia se tornou o aprofundamento e a verificação desse sujeito em sua experiência atuando em Santa Maria.

Definimos ainda, como forma de uma pré-apresentação dos nossos dados, apontar alguns elementos presentes em uma entrevista realizada pelo jornal "Sul 21" com um casal de professores do Rio Grande do Sul. A proposta da matéria foi mostrar como se encontra a vida desses docentes "após mais de 30 meses de parcelamento" de salário - política protagonizada pelo governador do estado, José Ivo Sartori (PMDB) ${ }^{16}$. Contudo, antes de mais nada, iremos expor aqui qual o conceito de intensidade do trabalho que estaremos lançando mão. Então vamos a ele.

Poderíamos sintetizar a definição assim: "há intensificação do trabalho quando se verifica maior gasto de energias do trabalhador no exercício de suas atividades cotidianas" (Dal Rosso, idem, p. 21). Mas o que isto de fato significa? Para explicar de forma mais clara possível, Dal Rosso parte de uma definição do que é trabalho.

16 Em reportagem da "Gaúcha ZH" de abril do ano de 2018, podemos entender melhor o histórico do parcelamento de salários dos servidores do Poder Executivo. Disponível em: $<$ https://bit.ly/2NYhNFh $>$. Acesso em: 27/07/2018. 
Com base em uma perspectiva de Karl Marx, Dal Rosso (idem, p. 20, grifos nossos) destacou primeiramente que o "trabalho é a transformação da natureza realizada pelos seres humanos empregando para isso meios e instrumentos a seu dispor e seguindo um projeto mental". É bastante evidente que muita coisa se modificou da Revolução Industrial e das sociedades pré-industriais para cá, fato que leva a tensionar e a desenvolver essa definição. É com este pensamento em mente que o autor se preocupa em discutir a questão da materialidade e imaterialidade do trabalho.

Não é a nossa pretensão neste artigo aprofundar esse debate, mesmo o entendendo fundamental para análise de elementos da categoria profissional que observamos, contudo faz-se questão de destacar a problemática relevante de que, conforme o autor, "na atualidade o espaço ocupado pelo trabalho imaterial no conjunto das atividades humanas expandiu-se muito" (idem, p. 30). Segundo Dal Rosso, "as atividades, hoje, passam a incorporar cada vez mais tecnologias de informática, de comunicação e de automação, que por sua vez ocupam muito mais a dimensão de conhecimento, da inteligência prática e da emoção do trabalhador do que em épocas anteriores". Enfim, o que nós gostaríamos de destacar junto com o autor é que, sendo o trabalho material ou imaterial, o sujeito em atividade coloca em movimento todas as suas perícias e habilidades corporais, ou seja, "uma atividade concreta demanda em medida variável o concurso de todas as capacidades do trabalhador, ainda que a atividade faça uso mais focalizado, esta do esforço físico, aquela do cognitivo e uma terceira do afetivo" (idem, p. 20-21, grifo nosso). Isto é o mesmo que dizer que "quando um projeto mental se atualiza na prática, os sujeitos que o realizam gastam um volume variável de suas energias físicas", cognitivas e afetivas (idem, p. 20, grifos nossos).

O fato citado acima pontua que a "ideia de que todo o ato de trabalho envolve gasto de energia e, portanto, exige esforço do trabalhador, está na raiz da noção de intensidade" (idem). É da 
natureza do trabalho sempre gastar energia para realizá-lo, seja mais, seja menos. Em vista disso, salientamos que o que está em jogo aqui na discussão é "a maneira como é realizado o ato de trabalhar" (idem, grifo nosso), a qual, por sua vez, desemboca no grau de envolvimento e "de dispêndio de energias realizado pelos trabalhadores na atividade concreta" (idem).

Segundo Dal Rosso (idem, p. 21, grifo nosso), "a manipulação do grau de intensidade tem por objetivo elevar a produção quantitativa ou melhorar qualitativamente os resultados do trabalho"17. "Quando se trata de trabalho físico", por exemplo, "os resultados aparecem em medidas tais como maior número de veículos montados por dia por pessoa etc.". Quando o trabalho é de âmbito imaterial ${ }^{18}$, "os resultados podem ser encontrados na melhoria da qualidade mais do que na quantidade" (idem). Em síntese: "intensidade são aquelas condições de trabalho que determinam o grau de envolvimento do trabalhador, seu empenho, seu consumo de energia pessoal, seu esforço desenvolvido para dar conta das tarefas a mais", etc., tendo por "objetivo [...] elevar quantitativamente ou melhorar qualitativamente os resultados" (idem, p. 23). Um exemplo interessante seria o caso de um professor entrevistado, o qual chamamos de Irineu Funes (2018) ${ }^{19}$. Funes destacou que "aceitou" assumir a disciplina de Sociologia, mesmo não possuindo formação específica na área, por já ter uma aproximação com a mesma, o que seria dos males o menor, ou seja, com uma qualidade menos inferior que outro professor sem nenhum vínculo com esta área do conhecimento.

Dito isso, gostaríamos de apontar alguns instrumentos de intensificação de modo geral, o que não quer dizer que necessaria-

17 “No capitalismo contemporâneo, a análise da intensidade do trabalho está voltada para os resultados" (Dal Rosso, idem).

18 Pesquisador, educador, enfermeira, etc., para ficar nos exemplos do autor. Mais adiante iremos retomar esse assunto.

19 Destacamos desde já que, mesmo possuindo o documento de consentimento livre e esclarecido, optamos por utilizar nomes fictícios retirados de obras literárias. 
mente estejam todos interligados à esfera educacional pública ${ }^{20}$, mais especificamente na etapa do ensino médio. Boltanski e Chiapello (idem, p. 273) destacam, neste sentido, "os novos métodos de administração", sintetizados na maior divisão e autonomização de equipes ou seções de atividade; as "coações em termos de ritmo de trabalho" (idem, p. 274); os certificados de avaliação (idem, p. 275); "as novas tecnologias de informação" (idem); "o desenvolvimento da polivalência com salário igual” (idem, p. 277, grifos do original); os "novos filões de competências" (idem, grifos do original); e, "por fim, a tendência à individualização das situações de trabalho" (idem, p. 278, grifos do original). Ainda destacamos mais um: o "alongamento das jornadas" (Dal Rosso, idem, p. 109, grifos do original).

Foi apresentada a definição base de intensidade do trabalho da qual lançaremos mão, bem como de alguns instrumentos de intensificação que podem estar presentes em nosso objeto, contudo, será realizada algumas modificações a partir do contato com os dados empíricos. Como bem sublinhou Dal Rosso (idem, p. 22, grifo nosso), "há situações de intensificação que não correspondem a maiores ou melhores resultados". Esses contextos, conforme o autor, são compostos por elementos que apontam "para uma generalidade e supratemporalidade considerável do fenômeno, particularmente vinculado a formas não-capitalistas de organização do trabalho", motivos estes pelos quais Dal Rosso optou por desconsiderar essa dimensão em sua análise ${ }^{21}$. A nossa pretensão aqui, por outro lado, será a de demonstrar de que forma essas duas esferas de intensificação ${ }^{22}$ podem estar imbricadas (ou no mínimo presentes) no trabalho contemporâneo docente, mais especificamente o daquele que ministra a disciplina de Sociologia no ensino médio das escolas público-estaduais da cidade de Santa Maria.

20 Em razão do fato já mencionado de que a intensificação no trabalho ocorre de maneira heterogênea nos diversos ramos de atividades profissionais.

21 Não à toa o autor dedicou apenas um breve parágrafo para esclarecer essa questão. 22 A que visa produzir resultados quanti ou qualitativamente maiores e a que não visa (ou não consegue). 
Quais então as nossas hipóteses? Uma delas é que a intensificação laboral não necessariamente gera melhores resultados no trabalho docente. A segunda é que, conforme estes resultados, podemos observar impactos significativos em esferas como a identidade do trabalho, bem como no caráter de artífice da atividade docente. A terceira e última hipótese é a de que dependendo de como se dá a relação entre formação inicial e disciplina ministrada, o professor passa adquirir (ao menos naquele momento) certo tipo de pertencimento identitário com a profissão. Como bem provocou Dal Rosso (idem, p. 34-35, grifo nosso), “a pesquisa futura precisa aprofundar o estudo de como aparece a questão da intensidade nessas formas imateriais"23. É justamente essa empreitada que buscaremos dar início aqui.

\subsection{Apresentação dos dados objetivos}

Antes de adentrarmos nos elementos de ordem mais qualitativos, fazemos questão de expor de forma breve, organizada e objetiva os dados extraídos dos 64 questionários que mobilizamos neste texto. Como bem já mencionado, esses questionários abrangem professores e professoras do ensino médio e ensino fundamental, além de abarcar também aqueles que estão "apenas" atuando em cargos de gestão.

Tais dados foram obtidos no âmbito do projeto "Formação de professores da educação básica e outros atores sociais: Ciências Sociais na Interface entre a Universidade, Escola e Comunidade". Este projeto de extensão, vinculado à Universidade Federal de Santa Maria (UFSM) ${ }^{24}$, teve como objetivo desenvolver ações formativas vinculadas aos conteúdos trabalhados nas Ciências So-

23 “Os setores que fazem apelo mais à inteligência, à afetividade, à capacidade de representação cultural, à capacidade de relacionar-se são os serviços de educação e cultura, os de saúde, os serviços sociais, os de comunicação e telefonia, os bancários e de finanças, importação e exportação e outros que surgiram com a revolução informática" (Dal Rosso, idem, p. 33, grifo nosso)

24 Projeto sob coordenação da profa. Dra. Laura Senna Ferreira (UFSM). 
ciais para diversos atores coletivos da cidade de Santa Maria e região. Assim, parte do coletivo de professores do Departamento de Ciências Sociais se voltou para a realização de formação continuada de professores de Sociologia da rede básica de ensino, promovendo espaços de capacitação e atualização docente, a partir de cursos e atividades em conformidade com a própria demanda dos professores. Em 2017 foram realizados dois cursos de formação, operacionalizados em conjunto com a 8 ${ }^{\mathbf{a}}$ Coordenadoria Regional da Educação (CRE). Após a realização dos cursos, a partir dos questionários, foram coletados dados sobre o perfil, formação, atuação profissional e interesses formativos dos participantes.

0 total de questionários aplicados foi de 64, totalizando $59 \mathrm{mu}$ lheres $(92,2 \%)$ e cinco homens $(7,8 \%)$. 0 número de cidades abarcadas foi 17. Dos 64 professores, 63 responderam sobre sua carga horária. A maioria realiza 40 horas semanais: 44 professores $(69,84 \%) .14$ profissionais atuam 20 horas $(22,22 \%), 3$ fazem 60 horas $(4,76 \%), 1$ atua 30 horas $(1,6 \%)$ e mais 1 trabalha 56 horas $(1,6 \%)$.

No que toca ao âmbito de atividades, sublinhamos que dos 64 questionários 60 responderam. Observamos que destes 60 professores, 35 estavam ministrando disciplina: 17 atuando com disciplina somado a um cargo de gestão e 18 "apenas" dentro da sala de aula. Os outros 25 professores atuavam somente em gestão no momento que responderam os questionários.

No que toca às disciplinas, sublinhamos um elemento já mencionado aqui, a saber, a adequação e inadequação da formação. De 32 professores levados em consideração ${ }^{25}$, 13 se encontravam

25 No que se refere à discussão acerca de "adequado e inadequado", diferentemente da questão de "professores que ministram disciplina", onde o CAT foi contabilizado, gostaríamos de destacar que este não foi levado em conta. É por essa razão que há uma variação nos números dos dados. Para saber mais sobre o Certificado de Avaliação de Título, cf. sítio Designação SEE MG. 0 que é CAT? Como fazer o CAT? Quais as mudanças na prioridade do CAT? Disponível em: <https://bit.ly/2MfsVQK> Acesso em: 03/08/2018 
inadequados: 10 ministravam uma disciplina que condizia com sua formação mais uma outra que não condizia e 3 ministravam somente disciplinas que não condiziam com sua formação. Destes 13 inadequados, constatamos que $11(84,6 \%)$ se encontravam na área de humanidades ${ }^{26}, 1$ na área de exatas e 1 na área de letras.

\section{Somos Feitos de Átomos, mas também de História ${ }^{27}$}

Como prometido anteriormente, traremos neste momento, antes de adentrar nos nossos dados, a entrevista realizada pelo "Sul 21"28. A intenção, como já destacado, é sublinhar alguns elementos da vida docente para posterior aprofundamento. Lembramos novamente que a categoria de professores vivenciou e vivencia uma situação dramática no que diz respeito ao pagamento de salários, o qual gera, no nosso entendimento, implicações mais graves na profissão. Vamos a algumas dessas consequências.

Começando pelo fim da entrevista, destacamos que não há como não lembrar da advertência de Dal Rosso (idem, p. 31): “é erro grosseiro supor que intensificação ocorre apenas em atividades industriais", isto é, no trabalho material. A professora Paola declarou, baseada em sua experiência de atuação em outras profissões, que nenhuma outra atividade chegou a ser tão desgastante quanto à docência. Não à toa que ela destaca a carga de cobrança vinda do Estado: são 16 turmas com uma média de 25 alunos, totalizando cerca de 400 alunos pelos quais ela é responsável.

O alto volume de cobrança, como bem destacou o professor Marcelo, também está vinculado ao aumento da carga horária que

26 Consideramos Sociologia, Ensino Religioso, Relações Humanas, Filosofia e História. 27 Na apresentação do seu livro intitulado "Os Filhos dos Dias”, Eduardo Galeano proferiu a seguinte assertiva: "os cientistas dizem que somos feitos de átomos, mas um passarinho me contou que somos feitos de história". A nossa intenção aqui foi de aproveitar as duas partes dessa frase.

28 Cf. link para acesso ao sítio na nota de rodapé no 01 . 
eles receberam, o qual, por sua vez, não culminou em um aumento de salário. Ou seja, há mais aulas para preparar, mais provas e trabalhos para corrigir e mais alunos para atender. Paola ainda sublinhou que com o aumento da carga horária, o trabalho frente ao aluno cresceu e o de casa diminuiu. Eis já presente um dos instrumentos da intensificação do trabalho.

A situação se faz mais dramática ainda pelo fato de que, para além da falta de reajuste, os salários estão parcelados há mais de 30 meses $^{29}$. Este elemento traz, obviamente, um impacto significativo na vida de quem depende unicamente da profissão para sobreviver. Sem entrar necessariamente no mérito dos reflexos da política do parcelamento na vida privada ${ }^{30}$, gostaríamos de ressaltar uma questão que consideramos interessante. Logo no início da entrevista, Paola destacou a dificuldade que encontra para comprar livros: "eu preciso comprar livros, né, professores precisam se nutrir do que acontece".

O que observamos nessa frase diz respeito ao tempo e envolvimento com o trabalho. Se levarmos em consideração a opinião de alguns dos nossos entrevistados, essa necessidade de comprar livros para se atualizar diz muito da falta de uma política de formação para os docentes, o que leva a categoria a buscar por conta própria esta formação. Assim poderíamos começar a explorar essa dimensão da intensificação no trabalho docente, focando nas entrevistas por nós realizadas.

Antes de mais nada, destacamos que das cinco entrevistas consideradas para este artigo, quatro foram com professores que ministram a disciplina de Sociologia nas escolas público-estaduais da cidade de Santa Maria e uma com um professor que se encontrava nesta mesma função em outra cidade. Sublinhamos

29 Cf. nota de rodapé 14, reportagem da "Gaúcha ZH".

30 Abandono de determinado estilo de vida, como por exemplo a exclusão da carne do cardápio ou a obrigatoriedade de andar a pé ou a privação de viajar nas férias, etc. 
que somente este último está presente na conta de professores que apenas foram aplicados questionários.

Que o professor precisa se atualizar dos conteúdos que ministra é um fato ${ }^{31}$ (Oliveira, 2009), o que fizemos questão foi de verificar como se encontra esta demanda na disciplina de Sociologia. Para tal, apontaremos alguns elementos gerais para depois chegar ao particular.

O Censo Escolar de 2017 realizado pelo Inep demonstrou que apenas 29,5\% dos e das docentes de Sociologia do país estão com formação adequada ${ }^{32}$ na área. É a pior taxa dentre as disciplinas. Aqui em Santa Maria não é diferente. Do total de 50 professores pesquisados no ano de 2015, apenas cinco possuíam a formação em Sociologia ${ }^{33}$.

O propósito aqui, como já mencionado, é observar de que forma ocorre o envolvimento no trabalho levando em consideração a formação e as condições objetivas de organização da escola.

Para dar início, destacamos que foram observadas escolas localizadas em dois extremos. Uma delas conta com uma gestão democrática funcionando, planos de aulas sendo elaborados em conjunto para harmonizar os conteúdos, estrutura física podendo ser bem utilizada, etc. Já a outra possui uma estrutura mais

31 Para além das atualizações na realidade social e cultural dele e dos seus alunos.

32 Essa adequação diz respeito à formação inicial dos professores e às disciplinas que lecionam em determinada escola. Desses 29,5\%, sublinhamos que 27,1\% são "professores com formação superior de licenciatura (ou bacharelado com complementação pedagógica)" em Sociologia, ou seja, a formação mais adequada possível, enquanto 2,4\% são "professores com formação superior de bacharelado (sem complementação pedagógica)" em tal disciplina. É a pior taxa dentre as disciplinas do ensino médio, seguida por Artes, com respectivamente 41,1\% e 9,5\%. Tais informações se encontram na página 22 das Notas Estatísticas do Censo Escolar de 2017. Disponível em: < https://bit.ly/2AqicOL>. Acesso em: 25/06/2018.

33 Cleber do Nascimento. Ensino de Sociologia: formação dos docentes e o ensino nas escolas estaduais de Santa Maria/RS. Publicado em Universidade Federal de Santa Maria. Disponível em: <https://bit.ly/2AN37a4>. Acesso em: 29/06/2018. 
verticalizada, com menor diálogo para planejar as matérias de forma compartilhada, problemas com a estrutura física, etc. As outras três escolas variam entre esses extremos.

Dito isso, passamos para o quadro contendo informações dos professores e das professoras de Santa Maria que foram entrevistados/as e posteriormente as entrevistas.

Quadro 1 - Listagem das professoras e dos professores entrevistadas/os ${ }^{34}$

\begin{tabular}{l|l|l|l|l}
\hline Nome $^{35}$ & Vínculo & Idade & $\begin{array}{l}\text { Tempo de } \\
\text { Profissão }\end{array}$ & Graduação \\
\hline Alice & Concursada & 33 & 7 anos & Ciências Sociais (licenciatura) \\
Bento Santiago & Concursado & 31 & 5 anos & História \\
Irineu Funes & Concursado & 26 & 3 anos & História \\
Jean Valjean & Contratado & 37 & 3 anos & História e Jornalismo \\
Úrsula Iguarán & Concursada & 51 & 25 anos & Ciências Sociais (licenciatura) \\
\hline
\end{tabular}

Fonte: dados coletados pelos próprios autores, 2017-2018.

Começaremos pelo professor que não atuava na cidade de Santa Maria. Escolhemos ele por entendermos que esse é o caso mais dramático dentre os entrevistados. Chamaremos ele de Jean Valjean, protagonista do livro Os Miseráveis, de Victor Hugo.

Jean Valjean, de 37 anos na época, sendo três na profissão docente, com formação inicial em Jornalismo e História, porém ministrando Sociologia e Filosofia, já se diferenciava dos outros entrevistados pelo seu vínculo empregatício. Diferente dos demais que são concursados, Valjean se encontrava como contratado. Nesta parte do relato o elemento de insegurança se fazia presente: "a situação do contrato não existe certeza nenhuma não precisa nem chegar o

34 Parte da forma dessa tabela foi inspirada na que fora elaborada por Jorge Fuentes em sua dissertação intitulada "A precarização do trabalho docente e a disciplina de Sociologia no ensino médio" (2015).

35 Destacamos que os nomes fictícios são todos inspirados em personagens de literatura a fim de preservar a identidade dos professores. 
fim do ano [...] pode ser amanhã [...] ó vamos nomear alguém aqui e não precisamos mais de ti e não precisam nem me indenizar". Essa insegurança o faz planejar outras formas de sobrevivência, como por exemplo a sua atuação na época em outra profissão para além da docência ${ }^{36}$. Ademais, a falta de certeza quanto a um futuro a longo prazo na atividade educacional o fazia flertar com a ideia de abandonar a profissão docente.

Segundo Nise Jinkings (2009, p. 05) os estudos e pesquisas na área do trabalho docente têm apontado esses elementos de multiemprego, para além da baixa remuneração, "precárias condições formativas e de trabalho", etc. Levando em consideração a questão formativa que teoricamente seria responsabilidade do Estado, o entrevistado considerou "uma piada é uma das coisas na educação que é uma piada", isto pelo fato de serem cursos pouco esquematizados e extremamente pontuais. A situação ainda piora pelo fato de ele não possuir a formação das disciplinas que na época ministrava. Além disto, todos os demais entrevistados problematizaram a questão dos cursos de formação que deveriam ser realizados pelo governo ${ }^{37}$, os quais estão previstos no plano de carreira e que na maioria das vezes não são oferecidos ou não são geradas as condições para o profissional se fazer presente ${ }^{38}$.

36 Lembramos aqui novamente Marcelo, o entrevistado do "Sul 21" que fora citado anteriormente, o qual procurava realizar um curso de corretagem para atuar nas horas vagas como corretor.

37 Cf. Estatuto e Plano de Carreira do Magistério Público do Rio Grande do Sul. Disponível em: <https://bit.ly/2Q2rIv8>. Acesso em: 26/08/2018

38 Em uma conversa informal que tivemos com um dos entrevistados, o mesmo salientou a importância de se realizar cursos de formação que façam "rodízios" nas escolas, em vista de que muitas vezes os professores não conseguem liberação da direção. Fato este que entra em contradição com o Estatuto e Plano de Carreira citado logo acima. Nesse sentido que umas das questões que nos chamou a atenção nos 64 questionários analisados aqui. Dos 60 professores que responderam sobre sua ocupação na escola, apenas 18 possuíam sua atividade voltada estritamente para a sala de aula, enquanto que 42 estavam vinculados a alguma atividade de gestão. Fica a pergunta: a partir destes dados é possível afirmar que há uma maior facilidade por parte dos gestores em frequentar estes cursos? 
Na pergunta que diz respeito ao impacto da falta de formação em Sociologia nas aulas e sua vinculação com esta, o professor respondeu que

pra mim é a mais difícil, mais difícil que qualquer outra, porque não estudei Sociologia [...] me falta totalmente a base [...] sou um professor de Sociologia terrível, terrível, absolutamente terrível [...], os conhecimentos sociológicos que adquiri na minha caminhada lendo são muito [...] isolados, eles não formam, não dá pra fazer um organograma mental, sabe? [...] E isso é mais difícil pra mim, romper as barreiras na Sociologia do que na Filosofia, na Geografia, por causa dessa carência (Jean Valjean, 2017).

Conforme Jinkings (2007, p. 126), esse contexto acaba obstaculizando a "criação e a consolidação de espaços de reflexão sociológica que promovam mediações significativas entre os estudantes e o conhecimento científico da vida social", ou, dito de outra forma, são "experiências pedagógicas descontextualizadas e fragmentadas, que não permitem uma compreensão totalizante do mundo social contemporâneo".

É possível observar que esse fato difere dos professores que possuem a formação adequada. Alice (2018), por exemplo, afirmou de

que que adianta o aluno saber em detalhes a diferença entre solidariedade orgânica e mecânica... e não saber ver por exemplo que na realidade que ele vive a desigualdade social é um problema grave que tem um contexto histórico e social por trás disso... então eu quero que meu aluno saiba interpretar a realidade que ele vive...

Como ela bem ainda destacou, isso se torna mais fácil quando tido como objetivo e também quando experimentadas variadas experiências pedagógicas somadas à formação adequada. 
Em um meio termo dessa situação podemos encontrar Bento Santiago (2018), Irineu Funes (2018) e Úrsula Iguarán (2018) ${ }^{39}$. A última, contudo, consideramos mais adequada que inadequada, posto que vinha cursando Ciências Sociais ao mesmo tempo que lecionava a disciplina na escola. Neste sentido, ela não tinha problemas em ministrar Sociologia. Bento Santiago, por sua vez, apesar de sua formação inicial ser em História, também não o tinha. Afirmou que sempre gostou de Sociologia e lia os autores por fora do curso original. Já Irineu Funes é o mais insatisfeito com a situação. De acordo com sua fala, ele "não estudou e se formou para dar essa disciplina, não estudou a fundo os autores e os conceitos de Sociologia" e para além de se sentir incomodado, também não se sentia preparado para ministrá-la.

Observamos neste último o fato de ter que buscar a formação por conta própria. É nesses termos que compreendemos um dos níveis de intensificação do trabalho. Ou seja, o professor precisa dispender mais tempo e energia para se envolver com uma disciplina na qual ele não se formou, porém precisa ministrar. Esse aspecto se soma ao fato do Estado não oportunizar essa formação, fazendo com que o próprio professor utilize o tempo fora da escola (trabalho não pago) para ampliar suas qualificações. A ocorrência se tornava mais dramática pelo fato de Irineu possuir na época uma carga horária de 60 horas, 47 períodos por semana divididos em três disciplinas nos turnos da manhã, tarde e noite ${ }^{40}$.

Dos cinco professores entrevistados, dois trabalhavam em mais de uma escola. Irineu Funes, como já mencionado, se sentia muito satisfeito em trabalhar em uma escola e muito insatisfeito

39 Na época não se encontrava com formação em Ciências Sociais, graduação que em pouco tempo depois veio a obter. Neste sentido que colocamos no quadro licenciatura em Ciências Sociais.

40 Ele trabalha em mais de uma escola, realidade fortemente presente no Rio Grande do Sul. Para mais detalhes cf. sítio Zero Hora. Em jornadas triplas, professores se dividem entre escolas para melhorar o salário. Disponível em: <https://bit.ly/2ATZgYS >. Acesso em: 26/07/2018. 
em outra. Sublinhamos que a sua satisfação se vinculava a uma escola municipal que não se encontrava em Santa Maria. Alice (2018), por sua vez, também vive um dilema parecido: se sente realizada apenas em uma das escolas. A sua insatisfação é em decorrência da forma de organização da escola, bem como em relação aos aspectos físicos da instituição.

Outro elemento que gostaríamos de destacar é o que trata da gestão democrática nas escolas. Lançamos mão novamente das falas de Alice e Irineu Funes ${ }^{41}$. De acordo com Alice (2018), uma das escolas onde ela trabalha

é o exemplo perfeito de como deve funcionar a gestão democrática... todas as decisões da escola passam pelos professores, pelo Conselho Escolar, pelos pais e pelos alunos... então tudo é feito... a gente trabalha mais no "Luis Buñuel" ${ }^{42}$ porque tem um excesso de reuniões, mas... essas reuniões justificam a boa qualidade da escola... é uma qualidade muito boa... é um ambiente muito bom de trabalhar... os colegas que tão lá normalmente se adaptaram a esse ritmo e abraçam a causa da educação pública de qualidade... então é um grupo de trabalho muito bom... (grifos nossos).

E é nesses termos que compreendemos que a intensificação pode aparecer no trabalho docente em forma de maior qualidade. Diferentemente, por exemplo, do caso da outra escola de Alice, bem como na de Irineu Funes (2018). Conforme Funes, a gestão democrática é um

projeto que assim tem muita dificuldade na escola hoje... porque é daqueles projetos que novamente esbarram na atual formação de professores... então você tem uma lei... bonita... maravilhosa, muito legal, até por sinal muito bacana de gestão democrática, só que na prática ela não

41 A fala de Úrsula Iguarán é muito próxima a de Alice, portanto não a recorremos. 42 Nome fictício que demos à escola. 
acontece... você pode até encontrar um gestor que consiga ter, por exemplo, iniciativa de gestão democrática... eu duvido você encontrar uma escola que esteja de fato completamente de acordo com a lei... isso não existe... tu pode encontrar em uma escola são diretores que têm uma sensibilidade para fazer algumas que são democráticas, mas no geral o que acontece assim é o máximo o mais democrático que você tem nisso tudo é eleição dos diretores (Irineu Funes, 2018).

Além do mais, destacou que

os professores estão com tanta coisa pra fazer... hoje... muitos professores com 40, 60 horas... que eles não têm tempo, nem saco pra se envolver com a escola... ah tu vai me dar mais uma coisa de trabalho, já tenho que bater boca com aluno, já tenho que... perder tempo com disciplina, que é uma coisa que eu nem deveria tá perdendo tempo... eu tenho que perder com tudo isso e aí tu quer que eu tipo participe ainda mais, ter que fazer um projeto pra escola, de ficar votando coisa pra escola (idem).

Percebe-se, nesse sentido, que a forma como se gere a escola é fundamental quando diz respeito à questão da intensificação. Se a gestão democrática de fato minimamente funciona, como no caso da escola de Alice (2018), ela não é degradante e sente prazer em atuar assim. Se for como no exemplo de Irineu Funes (2018), a participação nas decisões da escola se torna mais um fardo para o docente. É assim que observamos as duas formas de intensificação imbricadas no trabalho docente.

\section{Considerações Finais}

Como tivemos a oportunidade de observar, algumas das condições objetivas do trabalho docente impõem a estes profissionais desafios com os quais precisam lidar cotidianamente. Seja no que diz respeito a esfera da organização da escola, seja no âm- 
bito da disciplina que leciona frente a sua formação de origem. Neste sentido, constata-se que a intensificação do trabalho cria dilemas para que o professor realize a condição de artífice na sua atividade, a qual, por sua vez, compõe sua identidade profissional.

Só para recordar: o caráter de artífice para Sennett (idem, p. 19) é o desejo do trabalho realizado com qualidade, "bem feito por si mesmo", o qual o sujeito que o faz sente satisfação daquilo que executou. Apenas para acrescentar: na busca por esse ótimo resultado a rotina e a repetição se fazem fundamentais para 0 aperfeiçoamento do trabalho, sem se preocupar de forma negativa com o tempo e com o ritmo ${ }^{43}$. Como bem destacou o autor, "uma orquestra ensaia com um regente convidado; ele trabalha obsessivamente com a seção de cordas, repetindo interminavelmente uma passagem para fazer com que os músicos ataquem as cordas com seus arcos exatamente na mesma velocidade" (idem, p. 29, grifos nossos). De certo que na profissão docente o fato não se faz totalmente diferente: o professor precisa ler e reler, marcar e remarcar um texto, necessita elaborar e reelaborar suas aulas, visitar e revisitar um conteúdo, fazer e refazer suas avaliações, etc. Neste sentido, de que forma um professor que possui determinada formação, porém ministra outra disciplina, consegue realizar os procedimentos de rotina e repetição, sendo que é necessário abrir frentes de tempo para se dedicar a algo que não se tem o domínio inicial? Esta problemática ficou bastante evidente nos relatos de Jean Valjean e de Irineu Funes.

No primeiro caso, destacamos ainda o fato do entrevistado possuir um filho na época e também trabalhar em outra atividade para além da docência. Nas palavras de Jean Valjean (2017): “eu

43 Nesse sentido é impossível não lembrar de todos os professores entrevistados aqui. Como a disciplina de Sociologia possui apenas um período, os profissionais afirmaram que a rotina em sala de aula é entrar, tentar organizar a turma, fazer a chamada e quando vê já se passou 15 ou 20 minutos. A questão do tempo que a disciplina tem na grade curricular é um dos elementos que fazem com que os professores muitas vezes precisem aumentar o ritmo em sala de aula. 
tenho muitas vezes dificuldade com o tempo pra preparar aula, sabe? Por causa desde que eu trabalho como professor eu também trabalho como produtor, também trabalho com outras coisas, também sou músico [...], tenho um filho pequeno". No caso do segundo, apesar de gostar de Sociologia e de ter feito "uma dissertação dialogando com esta área", Irineu Funes (2018) admite que precisa investir por conta própria em estudos para poder ministrar esta disciplina da melhor maneira possível, ciente de que não é "capaz de fazer isso como um profissional com formação neste domínio". Ele ainda pontuou que o caráter atemporal dos conteúdos da disciplina auxilia neste processo. Aqui podemos observar um dos elementos criativos que o entrevistado recorre para melhor se adaptar com a situação.

Irineu Funes ainda vivencia outra questão: a gestão democrática de sua escola, como bem já relatado anteriormente, não funciona da forma ideal, o que acaba se tornando, ao invés de algo produtivo, um fator de maior acúmulo de tarefas frente a condições que não possibilitam maior engajamento e qualidade nesta esfera. Além do fator da jornada de trabalho, Irineu Funes também abordou a problemática salarial: “quem é que tá motivado com um salário de fome desses a participar assim na escola como se fosse a própria casa... o professor ele quer dar sua aula e ir embora...". Estes são alguns dos fatores que levam Irineu Funes à insatisfação com essa escola para qual ele trabalha. Cabe menção, neste sentido, como bem sublinhou Dalila Oliveira (2009, p. 36), que se as obrigações legais desse tipo de gestão "representaram a conquista democrática da luta de décadas pela democratização da educação, é inegável que têm também produzido a intensificação do trabalho docente, já que as condições que o professorado trabalha não acompanharam tais mudanças".

Não menos dramática é a fala de Jean Valjean (2017) quando perguntado sobre o nível de satisfação com a profissão naquele momento. 
péssimo [...] a palavra é péssimo [...] hoje minhas aulas talvez sejam as piores que eu já dei na vida, sabe? 0 que eu já [...] mesmo na hora de preparar eu começo a ver coisas, ah vou botar isso aí, mas os alunos não vão dar bola, não adianta, aí vou dar atividade avaliativa eles não vão entregar [...] então as minhas aulas estão terríveis, péssimas mesmo [...] e eu se fosse um aluno que voltasse a ter 16 anos e tivesse naquela aula provavelmente ia pegar o celular

Observamos, como bem sublinhou Sennett (2009), que a habilidade de artífice não se faz apenas pela vontade individual do sujeito, mas também pelas condições de se exercer e empregar tal caráter em seu trabalho.

Retomando o debate sobre identidade, sublinhamos o ponto de vista de Claude Dubar. Buscando se afastar das perspectivas que enfocam ou na agência ou na estrutura, Dubar propõe um diálogo entre estas esferas. Conforme o autor "a identidade humana não é dada, de uma vez por todas, no nascimento: ela é construída na infância e, a partir de então, deve ser reconstruída no decorrer da vida" (Dubar, 2005, p. XVII). Neste sentido, "o indivíduo jamais a constrói sozinho: ele depende tanto dos juízos dos outros quanto de suas próprias orientações" (idem). Dubar, portanto, assim como Goffman (1988) e Strauss (1999), defendeu que "a identidade é produto das sucessivas socializações" (idem).

Trazendo para a dimensão da profissão, Claude Dubar (2009, p. 117-118) sublinhou que "as identidades profissionais são maneiras socialmente reconhecidas, de os indivíduos se identificarem uns aos outros no campo do trabalho e do emprego". Como bem destacou o autor,

quer sejam chamadas de "ofícios", "vocações", ou "profissões", essas atividades não se reduzem à troca econômica de um gasto de energia por um salário, mas possuem uma dimensão simbólica em termos de realização de si e de reconhecimento social. [...] É por e em um processo específico 
de socialização, ligando educação, trabalho e carreira, que essas identidades se constroem no interior de instituições e de coletivos que organizam as interações e asseguram o reconhecimento de seus membros como "profissionais" (Dubar, 2012, p. 354).

Como constatado, nessa perspectiva não se trata de observar a identidade como algo estável e harmonioso, mas, sim, como um processo conflituoso e muitas vezes radical, que pode ser observado nas narrativas dos sujeitos. Sendo assim, percebemos pelos relatos dos nossos entrevistados, mesmo estando eles na mesma profissão, identidades profissionais heterogêneas. Sublinhamos que enxergamos este elemento compreendendo que a identidade docente é deveras muito complexa, ainda que o nosso recorte seja especificamente sobre aqueles que lecionam no ensino médio.

Dito isso, ressaltamos que a partir das entrevistas conseguimos observar três tipos de identidades de professores que ministram Sociologia no ensino médio das escolas público-estaduais da cidade de Santa Maria. O primeiro tipo que destacamos é o de caráter mais coincidente, ou seja, a formação inicial corresponde à disciplina que o profissional ministra. Foram enquadradas nesta percepção Alice (2018) e Úrsula Iguarán (2017). Ousamos dizer que, pegando emprestado o termo de Robert Castel, nesses casos há uma maior "filiação identitária"44.

O terceiro molde seria o mais dramático e se enquadram aqui os profissionais que não atuam na área onde se formaram inicial-

44 Uma pequena nota para esclarecer uma questão. Essas definições, como bem já abordadas no debate sobre identidade, não são estanques, ou seja, é possível variar conforme determinações estruturais e trajetórias de vida. Cito como exemplo um trecho da fala de Alice (2018). Ela ministra Sociologia e também Filosofia. Quando abordou a questão da Filosofia, a entrevistada respondeu que "não sabia porque tinham feito isso", ou seja, porque tinham colocado ela para ministrar esta disciplina. 0 que queremos destacar aqui é uma possibilidade desse fato mudar no futuro, seja com ela ministrando apenas Sociologia (que é sua formação), seja com ela ministrando apenas Filosofia. Entendemos, neste sentido, que poderiam haver variações em sua identidade profissional conforme mudasse essas condições de trabalho. 
mente. Além deste fato objetivo, os relatos sublinham a pouca identificação com a disciplina de Sociologia. Aqui poderíamos dizer que se encaixam Irineu Funes e Jean Valjean ${ }^{45}$. Nestes casos, novamente adaptando para nossa pesquisa os termos de Castel, afirmamos que há uma maior "desfiliação identitária"46.

O segundo tipo seria o intermediário entre os dois "extremos". De maneira objetiva, trata-se dos que não possuem formação inicial na área, ministram a disciplina de Sociologia e possuem um vínculo de identificação com esta matéria. Colocamos nesta perspectiva Bento Santiago que, para além de sua Pós-Graduação em Ciências Sociais, nos relatou que sempre gostou desta área e mesmo quando cursava História lia os autores de Sociologia.

Realizados esses apontamentos, gostaríamos de resgatar uma questão. No início do texto foi dito que pensaríamos os elementos dramáticos e/ou criativos da profissão docente. Adentramos agora, portanto, no debate sobre os segundos. Estes, por sua vez, se farão divididos em três partes. A primeira no que diz respeito ao ensino de Sociologia, a segunda ao tema da organização da

45 Este último, como já destacado, não se encontrava em Santa Maria, porém o levamos em consideração na pesquisa.

46 Gostaríamos de esclarecer a utilização desses dois termos. Robert Castel em "Metamorfoses da Questão Social" (2015) analisa a degradação dos pilares da sociedade salarial que se segue ao fim do Estado de bem-estar social. A partir do conceito de "vulnerabilidade social" procura estabelecer a ligação entre a precariedade do trabalho e a fragilidade dos vínculos sociais, quer dizer, evidenciar as relações entre precariedade econômica e instabilidade social. A economia no período neoliberal fortalece a lógica da competitividade do mercado e fragiliza os laços sociais, a "solidariedade", o pertencimento coletivo e o "pacto social". A desestabilidade dos estáveis e a instalação da precariedade (emprego descontínuo, por exemplo) promovem uma crescente degradação das funções integradoras desempenhadas pelo trabalho. Como corolário a precarização do "capital relacional" - relações de vizinhança, família, participação em grupos, sindicatos, partidos... -, provocando um isolamento e uma "desfiliação" social, quer dizer, uma vida a qual falta sentido, projetos e objetivos. Se a filiação identitária tem a ver com um indivíduo vinculado a uma rede de pertencimento, direitos, proteções e vínculos sociais, a noção de desfiliação remete a uma relação entre a degradação da situação econômica e a desestabilização dos modos de vida, pondo os indivíduos numa condição de vulnerabilidade e fragilização dos vínculos de pertencimento. 
escola e a terceira sobre um relato acerca da Reforma do Ensino Médio. Como veremos, teremos a oportunidade de observar a gestão de si mesmo em alguns relatos.

Sobre o ensino de Sociologia, prezamos primeiro em ressaltar os que não possuem a formação, nem a identificação com a disciplina. Apesar dos dilemas mencionados aqui, no que toca os aspectos de inventividade, Jean Valjean (2017), por exemplo, destacou que

em duas escolas que eu lecionei elas tinhas excelentes livros ... livros curtos cheios de exemplo, cuja linguagem é até possível com alunos, na escola que estou agora o livro é gigante e ele é complicadíssimo mesmo para mim [...] então não me ajuda em nada [...] nessa questão eu uso o livro da outra escola transformado em esquemas e quadros e coisas assim e material é isso.

[...] então [...] eu procuro [...] escolher unidades do livro como base [...] pinçar trechos daquele livro geralmente que eu considero especialmente importante pra compreensão e daí eu vou em busca de alguma coisa que possa me adicionar, vou atrás de um filme que vá corroborar pra ajudar na formação, vou atrás de textos de outros autores, às vezes documentários, aproveitar que tem data show, hoje tá muito comum as salas de aula terem data show [...] até música mais raramente.

Irineu Funes (2018), por sua vez, sublinhou que, se por um lado é negativo ministrar Sociologia por causa da sua formação, por outro é positivo em decorrência dos debates que podem se apresentar por meio dela. Conforme seu relato, destacou que dentro das condições que se encontra ele "tem dado o seu melhor para dar esta disciplina", mobilizando temas como política, gênero, sexualidade, etc. 0 planejamento das aulas se dava por meio "da escolha do livro que estivesse mais próximo daquilo" que ele entendia e o que ele pensava da sua ideologia como educador e que também tivesse um retorno 
bom para os assuntos da escola. Além dos livros, Irineu Funes lança mão de recursos da internet, vídeos, filmes, imagens, visando a melhor forma de passar conteúdos, como os de política, aos seus alunos.

Sobre os que possuem a formação adequada, um relato interessante é o de Alice (2018). Como bem destacou, para lecionar a disciplina de forma que agradasse a ela, foram necessárias diversas experimentações no que diz respeito às formas pedagógicas de se trabalhar em aula. Observamos, neste sentido, que a formação é relevante, contudo, cabe ao professor saber utilizá-la bem na sua profissão.

No aspecto sobre as capacidades criativas de ministrar a disciplina, Bento Santiago (2018) sublinhou a necessidade de conseguir criar um diálogo entre a teoria e a prática, de forma consistente, sem focar estritamente nos conceitos. Segundo ele, essa é uma maneira de captar a atenção do aluno e fazer com que este perceba que de fato você sabe onde quer chegar e o que quer passar em sala de aula.

Indo para a questão que debate a organização da escola, começamos com um relato de Úrsula Iguarán sobre a gestão democrática. Úrsula Iguarán teve a oportunidade de trabalhar em escolas diferentes e presenciar realidades heterogêneas.

olha... eu já trabalhei em escola que não perguntavam nada pra ninguém... tinha que fazer alguma mudança no projeto político pedagógico aquilo vinha pronto... no início do ano ele, ah, a gente teve que fazer alguma mudança, a gente sabe que vocês são ocupados, a gente fez colocou isso e isso... já trabalhei em escola assim já vem pronto... e a.. aqui... na escola aqui que todos os documentos que são construídos, chamam os pais... a gente faz aquela discussão mais pedagógica, mais... dura (risos)... como a gente... dos professores ali é os funcionários participam depois a gente chama os pais também... os alunos participam ali na escola (Úrsula Iguarán, 2017). 
O outro relato já trazido aqui é o de Alice. Ali também constatamos um maior envolvimento e construção por parte dos professores para com a escola. Neste sentido podemos observar que, quando dadas certas condições - ou no mínimo as mais básicas -, é possível realizar um trabalho de artífice, em que a criatividade do indivíduo entra em contato com as estruturas do local podendo, assim, gerar maiores possibilidades de se realizar um trabalho de qualidade.

Nesta terceira e última parte, reproduziremos a narrativa de Úrsula Iguarán sobre a Reforma do Ensino Médio. A entrevistada, depois que ficou sabendo da reforma, prontamente começou a pensar em uma forma de garantir a empregabilidade se adaptando ao novo contexto que vem pela frente. Ela analisou e achou que realizar um curso sobre empreendedorismo fosse uma das opções bastante viáveis, pois sabe que tanto sociologicamente quanto no cotidiano da vida "comum" esta modalidade de trabalho está altamente na ordem do dia. Pode-se perceber, como pontuou Giddens (idem, p. 11), que "nas condições da modernidade, o futuro é continuamente trazido para o presente por meio da organização reflexiva dos ambientes de conhecimento", além de podermos constatar de forma bastante marcante a gestão de $\mathrm{si}^{47}$.

Em vias de conclusão, um último elemento chamou bastante atenção por aparecer em todas as entrevistas. Trata-se da questão da saúde no ambiente de trabalho. Os cinco professores pontuaram a dramaticidade de muitos colegas profissionais que vivem com fragilidades no âmbito da saúde. Este fato é relevante para pensar alguns apontamentos futuros: a questão da saúde do professor está somente vinculada ao trabalho na escola? Como medir isto? De que maneira constatar da melhor forma possível o diálogo entre o estresse que vem de casa e o estresse que sai do trabalho? Enfim, que a questão da saúde se modifica

47 Pontuamos que o debate sobre a gestão de si pode ser verificado, se não de forma tão explícita, ao menos implicitamente em diversas partes dos relatos dos sujeitos que aqui foram entrevistados. 
frente às novas reestruturações laborais é um fato (Alves, idem; Dal Rosso, idem; Boltanski e Chiapello, idem), cabe observar como se dá esses impactos na esfera escolar.

\section{Ref erências}

Antunes, Ricardo. Os sentidos do trabalho: ensaio sobre a afirmação e a negação do trabalho. São Paulo: Boitempo, 1999.

Antunes, Ricardo; Alves, Giovanni. As mutações no mundo do trabalho na era da mundialização do capital. Educação e Sociedade, Campinas, v. 25, n. 87, p. 335-351, maio/ago., 2004.

Boltanski, Luc; Chiapello, Ève. 0 novo espírito do capitalismo. São Paulo: Martins Fontes, 2009.

Braverman, Harry. Trabalho e capital monopolista: a degradação do trabalho no século XX. Rio de Janeiro: JC Editora, 1987.

Dal Rosso, Sadi. Mais trabalho!: a intensificação do labor na sociedade contemporânea. São Paulo: Boitempo, 2008.

Dardot, Pierre; Laval, Christian. A nova razão do mundo: ensaios sobre a sociedade neoliberal. São Paulo: Boitempo, 2016.

Dubar, Claude. A Crise das Identidades: A Interpretação de uma Mutação. São Paulo: Edusp, 2009.

A construção de si pela atividade de trabalho: a socialização profissional. Cadernos de Pesquisa. São Paulo, v. 42, n. 146, p. 351-367, mai./ago., 2012.

A Socialização: construção das identidades sociais e profissionais. São Paulo: Edusp, 2005.

Giddens, Anthony. Modernidade e identidade. Rio de Janeiro: Jorge Zahar, 2002.

Goffman, Erving. Estigma e identidade social. Rio de Janeiro, Guanabara: 1988.

Jinkings, Nise. Ensino de Sociologia: particularidades e desafios contemporâneos. Mediações, Londrina, v. 12, n. 1, p. 113-130, jan/jun., 2007.

Trabalho e educação: o ensino de sociologia em escolas brasileiras. In: XXVII Congreso de la Asociación Latinoamericana de Sociología. VIII Jornadas de Sociología de la Universidad de Buenos Aires. Asociación Latinoame- 
ricana de Sociología, Buenos Aires, 2009.

Martins, Heloísa Helena. 0 ensino de métodos e técnicas de pesquisa nos cursos de Ciências Sociais. In: Cronos. Natal-RN, V.8, n.2, jul./dez., 2007.

Minayo, Maria. Ciência, técnica e arte: o desafio da pesquisa social. In: MINAYO, M. (org.) Pesquisa social: Teoria, método e criatividade. Rio de Janeiro-São Paulo: Abrasco-Hucitec, 1994.

Moraes, Amaury. Ensino de Sociologia: periodização e campanha pela obrigatoriedade. Cadernos Cedes, Campinas, v. 31, n. 85, p. 359-382, set./dez. 2011.

Oliveira, Dalila. A intensificação do trabalho docente e a emergência de nova divisão técnica do trabalho na escola. InterMeio: revista do Programa de Pós-Graduação em Educação, Campo Grande, v. 15, n. 29, p. 32-45, jan./jun. 2009.

. A Reestruturação Produtiva do Trabalho Docente: Precarização e Flexibilização. Educação e Sociedade, Campinas, v. 25, n. 89, p. 1127-1144, set./ dez., 2004.

Sennet, Richard. 0 Artífice. Rio de Janeiro: Record, 2009.

Strauss, Anselm. Espelhos e máscaras: a busca de identidade. São Paulo: Universidade de São Paulo, 1999.

Tragtenberg, Maurício. Burocracia e ideologia. São Paulo: UNESP, 2006.

\section{Entrevistas}

Alice. Intensificação laboral e identidade profissional [mar. 2018]. Entrevistador: Dionas Ávila Pompeu. Santa Maria. 1 arquivo .mp3 (104 min.).

Funes, Irineu. Intensificação laboral e identidade profissional [jan. 2018]. Entrevistador: Dionas Ávila Pompeu. Santa Maria. 1 arquivo .mp3 (77 min.).

Iguarán, Úrsula. Intensificação laboral e identidade profissional [nov. 2017]. Entrevistador: Dionas Ávila Pompeu. Santa Maria. 1 arquivo .mp3 (155 min.).

Santiago, Bento. Intensificação laboral e identidade profissional [mar. 2018]. Entrevistador: Dionas Ávila Pompeu. Santa Maria. 1 arquivo .mp3 (74 $\min$.$) .$

Valjean, Jean. Intensificação laboral e identidade profissional [out. 2017]. Entrevistador: Dionas Ávila Pompeu. Santa Maria. 1 arquivo .mp3 (100 min.). 